\title{
ARCHITECTURE IN THE ISLAMIC VISION
}

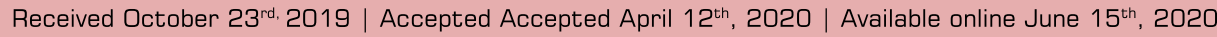
DOI http://dx. doi.org/10.18860/jia.v6i1.7867

\section{Yehia Hassan Wazeri}

Dept. of Architecture

High Institute of Engineering and Technology, Al Arish, Egypt.

drwazeri@yahoo.com

\section{ABSTRACT}

\begin{abstract}
The Qur'an contains about eighteen verses that refer to the architecture of the earth. Nearly two hundred elements (terminologies) of architecture and town planning have been mentioned in the Quran. This paper aims to present examples from the Quran to shed light on the Islamic vision of architecture and art. It uses content analysis method to achieve the objective of the research. The analysis is done by studying and discussing verses of the Holy Quran, which is related to architecture and urbanism. One of the most important results of this research is to give distinct architectural and urban examples, include the following: building materials, environmental architecture, houses of insects, visual illusions in architecture, and the centrality of Mecca to the world. All of them is explained in the Qur'an verses, such as Al-Baqarah, An-Naml, An-Nahl, Al-Kahf, and Al-Fajr.
\end{abstract}

KEYWORDS:

The Quran; Islam; Architecture; Town Planning

\section{INTRODUCTION}

Islam is not only a religion but a way of life for the happiness of man in this world and the hereafter. The Qur'an (The Holy book of Muslims) and the Sunna (The words and deeds of our Messenger Muhammad pbuh) are the primary sources of Islamic teachings and values. It is important to know the profound concept of architecture and art in Islam, through studying and discussing verses of the Holy Quran.

The Qur'an contains eighteen verses refer to the architecture of the earth, and some of them deduce the principles of this architecture. It was assigned to these Qur'anic verses in published books and papers [1].

Nearly two hundred elements (terms) of architecture and town planning have been mentioned in the Quran [2][3]. Also, some titles of Quran chapters are connected with architecture [2]. For example, the title of chapter eighteen is "The Cave," twenty-four is "The light," thirty-four is "Sheba" (old civilization/city), forty -nine is "The rooms," fifty-seven is "The iron" and ninety is "The city" (Mecca).

It is also important to note that the Qur'anic style always combines this artistic vision with the belief in God because any work in this life is also considered in Islam worship of God.

It can be realized through Qur'anic verses, in one of them Allah, the Exalted says:
"(Which then is best? He that layeth his foundation on piety to God and His good pleasure? Or he that layeth his foundation on an undermined sand-cliff ready to crumble to pieces? And it doth crumble to pieces with him into the fire of Hell. And God guideth, not people that do wrong.)" (Qur'an, 9:109).

According to one of the interpretation book, the meaning of the verse is [4]:

"Is he who founded his building upon fear of God (piety) and, in the hope of, beatitude, from Him, better, or he who founded his building upon the brink, the edge, of a bank, an overhang, that is crumbling, about to collapse (read juruf) so that it toppled with him so that it collapsed [taking] with it the one who built it, into the fire of Hell?: [this is] an excellent similitude for building upon that which constitutes the opposite of the fear of God and [for] what it leads to; the interrogative is meant as an affirmative: in other words, the former is the better, which is the likeness of the [building of the] mosque of Qubā', while the latter is the likeness of the mosque of 'harm' (masjid al-dirār). And God guides not the evildoing folk".

This paper aims to present some examples from the Quran to shed light on the Islamic vision of architecture and art. 


\section{METHODS}

This paper uses content analysis method to achieve the objective of the research. Content analysis is a research tool used to determine the presence of certain words or concepts within texts or sets of texts. The texts used in this study is Qur'an to find some concept of architecture.

\section{DISCUSSION}

\section{CONSTRUCTION MATERIALS}

The Holy Quran pointed out building materials, as well as some construction methods. These materials include the following:

a. The iron

In a chapter called "The iron" (Al-Hadid), the Qur'an referred to the importance of that material, describing it as strong and having multiple benefits. Allah, the Exalted says:

"(... and we sent down Iron, in which is (content for) mighty war, as well as many benefits for mankind...)" (Qur'an, 57:25).

The meaning is [4]:

"And we sent down iron, we caused it to be extracted from mineral ores, wherein is great might, with which one may wage battle, and [many] uses for mankind."

Moreover, there is a wonderful example in Surat Al-Kahf (the cave chapter). Illustrating the use of iron pieces with melted copper to construct a defensive backfill, to protect some people from enemies (Yagog and Magog people), and this means that the Holy Qur'an has indicated how to use metal alloys in defensive constructions.

Interestingly enough, it was found recently that adding a portion of copper to iron, increases its rigidity. The discovered technique is structurally sound and durable than steel reinforcing; the covering alloy is anti -rust and anti-erosion against the wind, water, and weather conditions [5]

\section{b. Burnt clay}

In a chapter named "Ghaafir," Pharaoh of Ancient Egypt said:

"O Hāmān, construct for me a tower (Sarah) that I might reach the ways" (Ghaafir: 36$)$. In another chapter named "Al-Qasas," a verse (no. 38) explains that this tower (Sarah) was of burnt clay, where Pharaoh said: "O eminent ones, I have not known you to have a god other than me, then ignite for me, O Haman, [a fire] upon the clay and make for me a tower (Sarah) that may look at the God of Moses. And indeed, I do think he is among the liars." (Qur'an, 28:38).

Orientalists have raised suspicions about the use of Burnt clay in ancient Egypt during the reign of Moses, and before the Roman era. However, there is some archaeological evidence that refutes this claim, the most important of which are the following [6]:

1. Burnt clay was used in the Predynastic grain-kilns at Abydos and Mahasna.

2. Burnt brick also used in the 1st Dynasty tombs at Saqqara.

3. There are examples of glazed tiles from the $1^{\text {st }}$ and 3rd Dynasties. It proves that the Egyptians, during the advent of the Old Kingdom Period, were aware of the glazing method.

4. The earliest models for using of burnt brick comes from the Middle Kingdom fortresses in Nubia, in which they were used as paving-slabs measuring " $30 \times 30 \times 5$ " cm.

5. Burnt clay is recorded in the New Kingdom Period when they occur in conjunction with funerary cones in the superstructures of the tombs at Thebes.

6. Burnt brick also appears at Nebesheh and Defenneh dated to Ramesside times.

From the extensive study of brick architecture in Egypt, "Spencer" concludes that [7]: "From the foregoing, it must be concluded that burnt brick was known in Egypt at all periods, but used only when its durability would give a particular advantage over the mud brick."

\section{c. The stone (rock)}

The Quran told us about the use of stones in construction, by referring to the people of "Thamoud" on the Arabian Peninsula. Where Allah the Almighty says: "... And Thamoud, who have brought the stone to the valley...." (Qur'an, 89:9).

\section{d. The silver}

Allah the Almighty says in chapter "AzZukhruf" (The decorations):

"And if it were not that the people would become one community [of disbelievers], we would have made for those who disbelieve in the Most Merciful - for their houses - ceilings and stairways of silver upon which to mount, And for their housesdoors and couches [of silver] upon which to recline,..." (Qur'an, 43:33-34).

Why did the Qur'an choose silver among all the other metals? The answer lies in the physical properties of this metal [8]:

1. Silver is the more heat-conducting metal.

2. Silver is the more electrically conductive metal.

3. Silver is white and the more metal reflecting light. Therefore, it is used in the manufacture of mirrors.

4. Silver is the rarest metal, except mercury (liquid).

\section{ENVIRONMENTAL ARCHITECTURE SIGNS IN THE QURAN}

In a chapter named "The cave," Allah, the Exalted says:

"And [had you been present], you would see the sun when it rose, inclining away from their cave on the right, and when it set, passing away from them on the left, while they were [laying] within 
an open space thereof. That was from the signs of Allah" (Qur'an, 18:17).

This verse refers to the particular relationship between the sun movement and the cave of the sleeping boys. All who are studying environmental architecture knows the importance of the relationship between the sun movement and the modern buildings design, fig. (1).

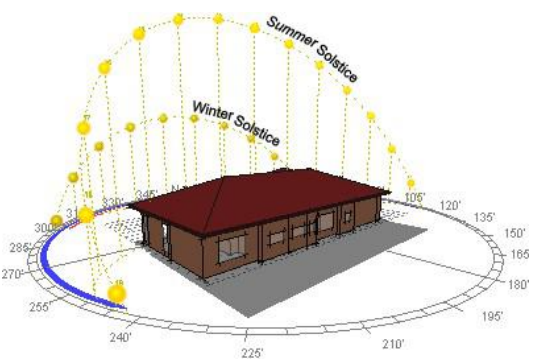

Figure 1. Sun path and building design

The Holy Quran also mentioned shade and shadows in more than one verse. For example, Allah, the Exalted says:

"And Allah has made for you, from that which

He has created, shadows and has made for you from the mountains, shelters and has made for you garments which protect you from the heat and garments which protect you from your [enemy in] battle. Thus does He complete His favor upon you that you might submit [to Him]" (Qur'an, 16:81).

All those who study environmental architecture know the importance of Shading in reducing temperatures, especially in the hot regions [9].

They also know the importance of clothing (garments) that protects against heat called the second skin [10], fig. (2).
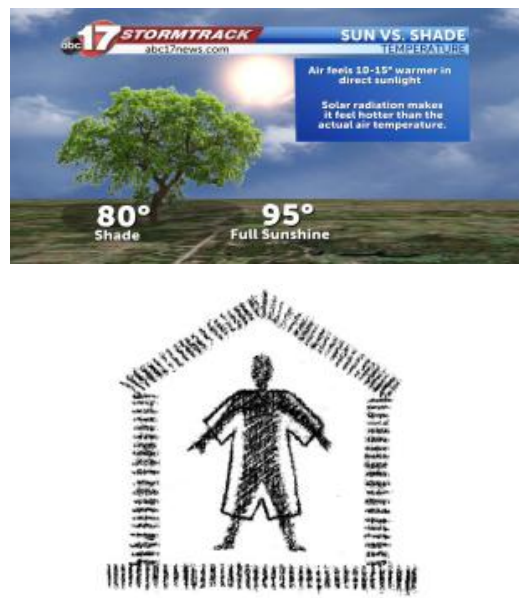

Figure 2. The importance of shade and clothes

\section{DIFFERENT TYPES OF INSECTS SHELTERS IN THE QURAN}

It is important to note that the names of some Quran chapters referred to some insects, such as bees, ants, and spiders (arthropods). These Qur'anic chap- ters mentioned the houses (nests) of bees and spiders as well as ants dwellings [11].

Biomimicry is now one of the important schools of modern architecture. Biomimicry is the study and imitation of living organisms (animals and plants) and natural elements (such as mountains, celestial bodies, etc.), in order to solve complex human problems. Biomimicry in building design is the simulation of systems and processes that occur in nature (such as insects and plants) [12] [13].

In "Ants" (Al-Naml) chapter, the Qur'an refers to the durability of the ants' dwellings where Allah, the Exalted says:

"One of the ants said: O ye Ants, enter your dwellings (habitations), and Solomon and his soldiers shall not strike you" (Qur'an, 27:18).

Entomologists have found that ant homes are similar to human dwellings because they are equipped with all functional needs such as food storage rooms and small ant rooms, as well as environmental aspects such as ventilation ducts, fig. (3).

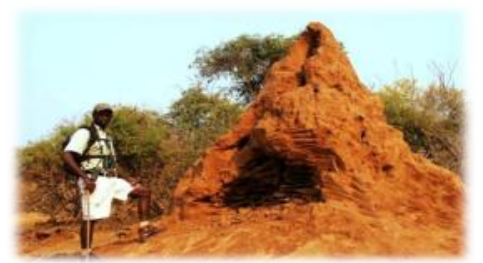

Figure 3. It is an anthill of white ants in Africa

The Holy Qur'an referred to the ants' homes for more than 1400 years, and this accurate reference is an amazing Quranic miracle.

In a chapter named "the bees" (Al-Nahl), the Holy Quran identifies the places where bees can build its shelters. These are mountains, trees, and in which humans construct, fig. (4).

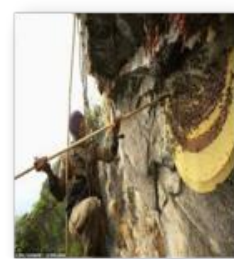

Mountains

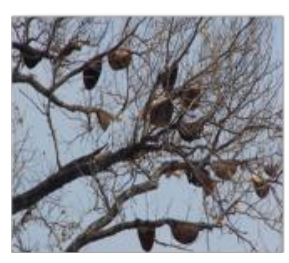

Trees

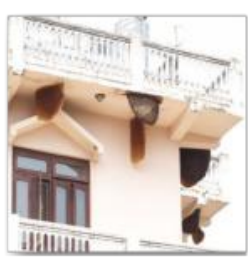

Buildings
Figure 4. The Holy Quran identifies the places where bees can be erect its shelters

Allah, the Exalted says:

"And your Lord inspired to the bees, take for yourself among the mountains, houses, and among the trees and [in] that which they construct" Qur'an, 16:68).

Finally, the Quran has also referred to the spider, as it is the weakest home ever, where Allah, the Almighty says:

"The likeness of a spider who builds (for itself) a house; but verily, the frailest (weakest) of houses is the spider's house - if they but knew" (Qur'an, 29:41). 
A spider home is a silk web created by a spider out of proteinaceous spider silk extruded from its spinnerets. It is a trap to catch its prey [14], fig (5).

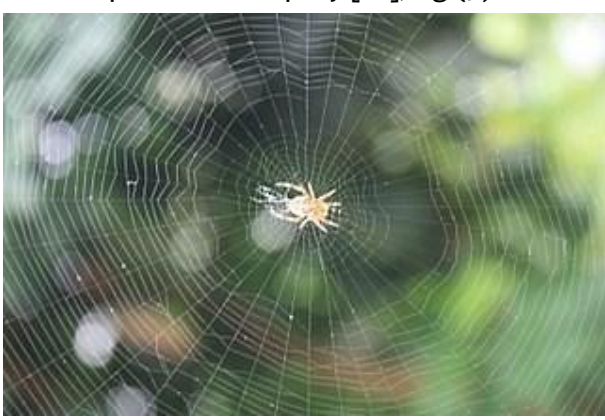

Figure 5. The spider web

\section{AN OPTICAL ILLUSION IN THE QURAN}

An optical illusion (also called a visual illusion) is defined as seeing things, colors, or materials in a way that is different from their true essence, fig. (6).

Op art, short for optical art, is a style of visual art that uses optical illusions. Typically, they give the viewer the impression of movement, hidden images, flashing and vibrating patterns, or of swelling or warping.

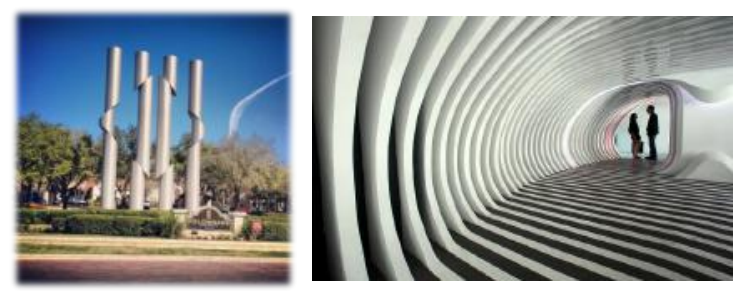

Figure 6. Two examples of optical illusion in architecture design

In her book "Beauty and Islam," Dr. Valerie Gonzalez confirmed that a verse (no.17) of "the Ants" chapter referred to visual illusion. She said that [15]:

"The optical illusion narrated in the Qur'an manifests the strong dialectic tension that animates this relationship (between nature and art)."

Dr. Valery explained what happened between the prophet Solomon and the Queen of Sheba, where he built an edifice of the crystal (Sarah) when the Queen of Sheba saw it, she thought it was deep water. The Queen of Sheba thought the crystal was deep water (optical illusion) so that she uncovered her legs.

Allah, the Exalted says:

"She was told, "Enter the palace (Sarah), But when she saw it, she thought it was a body of deep water and uncovered her legs, He said: "Indeed, it is a palace [whose floor is] made smooth with glass, "She said: "My Lord, indeed I have wronged myself, and I submit with Solomon to Allah, Lord of the worlds" (Qur'an, 27:44).

Techniques and methods of optical illusion in modern Architecture were used now. A contemporary example of this method is the interactive floors [16], which designed in different moving and natural forms, especially the deep water, fig. (7).
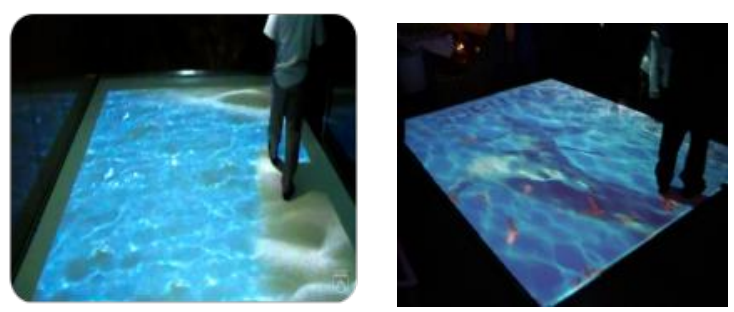

Figure 7. Interactive floors (deep water)

Another example was first created by Argentine designer "Leandro Ehrlich," who designed a Swimming pool with an illusory visual style. This pool is an artistic creation found in the 21st Century Museum of Art in Kanzawa, Japan. It was designed in 1999 and looks like a deep water pool, showing visitors in full clothes walking on its floor [17], Fig (8).

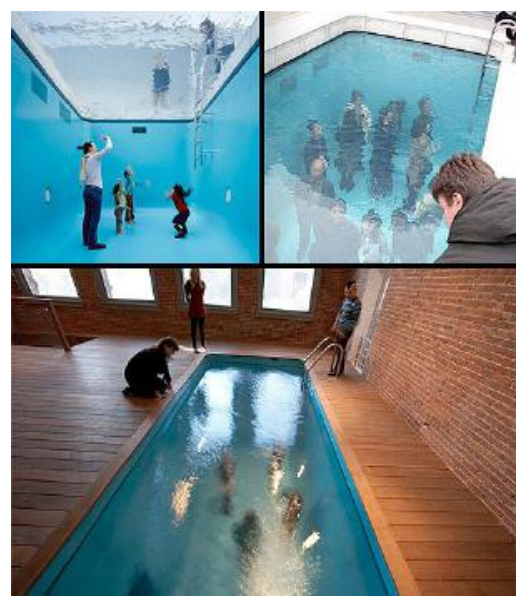

Figure 8. A swimming pool with an illusory visual style

\section{THE CENTRALITY OF MECCA IN THE QURAN}

According to the Holy Qur'an, the Kaaba is the first house set for people to worship Allah. So, Mecca (the mother of all towns) is the holiest city of Islam, where Muslims perform the annual hajj (pilgrimage) and Umra.

In the past, when Muslim scholars talked about Mecca as being superior to all cities of the world, they referred implicitly to the fact that Mecca is located in the center of the dry land.

For example, "Al Qortobi" explained the following Qur' anic verse:

"And so we have appointed you as a just and distinguished nation” (Qur'an, 2:143).

He said that [18]: "as the Kaaba is located in the center of the dry land, God appointed the Muslim nation as a just one due to its central location."

A recent study was conducted using measurements, and satellite images by Google Earth for Professionals proved that the sacred mosque of Mecca (the Ka'ba) is the center of the dry land [18]. It was found that it is located in the center of four circles that pass through the borders of the dry land of the world's, fig. (9). 

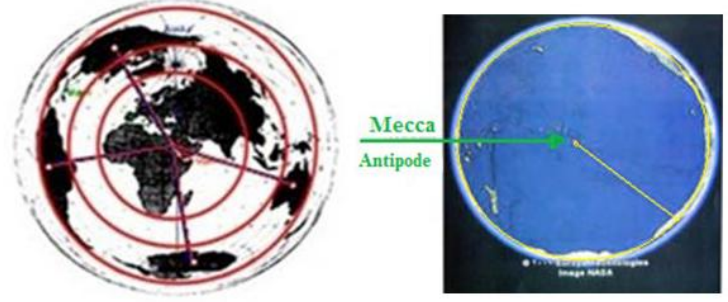

Figure 9. Mecca is the center of the dry land

American professor "Waldo Tobler" showed that Mecca is the only location on the earth that can be located in a unique location on the dry land by using equidistant azimuthal projection, centered on Mecca [19], fig. (10).

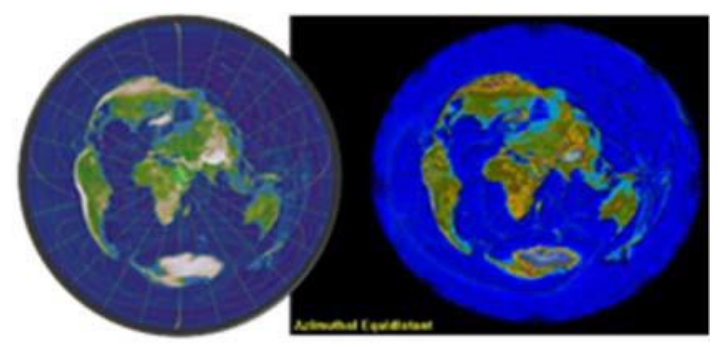

Figure 10. Waldo Tobler's equidistant azimuthal projection

Professor "Arnold Keyserling," who worked at Vienna University for more than 30 years, demanded that Mecca's longitude become the Prime Meridian rather than Greenwich. He said that : "The real meridian is not in Greenwich, but in Mecca, $40^{\circ}\left(39.49^{\circ} \mathrm{E}\right)$ longitude, with the cube of the Kaaba. The sacred center of Mecca marks the exact point of orientation".

Moreover, he drew a map of the world with a line passing through Mecca and in perfect alignment to the Polar Star to show that Mecca is the center of the dry land, fig. (11a).

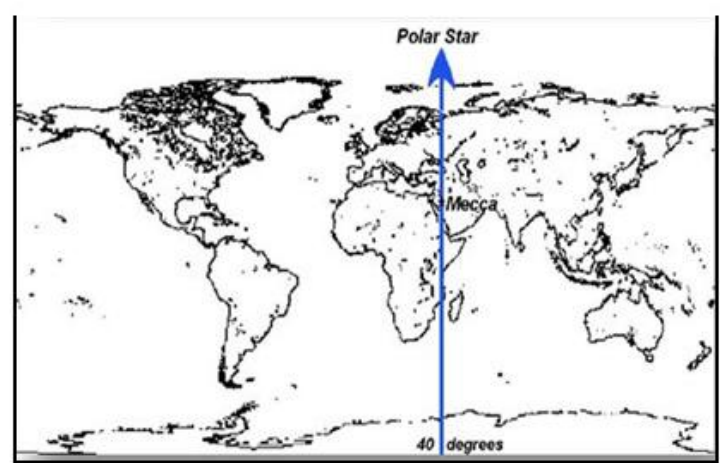

Figure 11a. The basic line of Global timing passing through Mecca

He also drew another map illustrating the different time zones making Mecca's longitude the beginning of global timing (Zero degrees), fig. (11b).

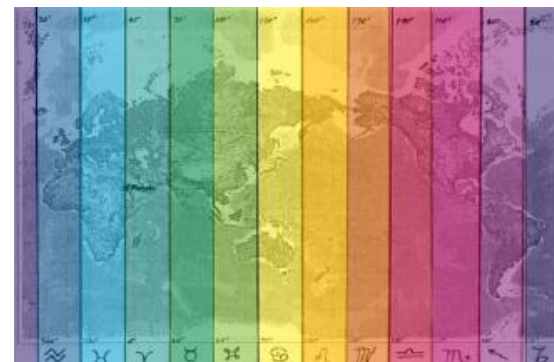

Figure 11b. Mecca's longitude the beginning of global timing

\section{CONCLUSION}

The research tried from these brief examples to illustrate the concept of architecture and art in Islam, specifically through the Holy Quran (the most important source of Islamic legislation).

The Qur'an's signs include the following: building materials, environmental architecture, houses of some insects, visual illusions in architecture, and the centrality of Mecca to the world.

There are other examples of Islam's respect for fine art and the architecture of the earth. Islam is a religion that respects the environment and promotes the love of beauty and creativity while at the same time does not neglect the moral aspects, thus guaranteeing happiness in earthly life and the hereafter as well.

\section{REFERENCES}

[1] Y. Wazeri, Urbanism and Building from Islam Viewpoint. kuwait: Kuwaiti Ministry of Endowments, 2008.

[2] G. Ikram, Architecture and Town planning in the Holy Quran. Lahore: Ferozsons, 1991.

[3] Y. Wazeri, "Architecture and urbanism terms in the Holy Quran," Towards an accurate and unified architectural language, 2013. [Online]. Available: www.sudacon.net $/ 2013 / 05 / \mathrm{blog}$ post_18.html.

[4] F. Hamza, "Tafsir al Jalalayn," The Tafsirs, 1459. [Online]. Available: https://www.altafsir.com/ Al-Jalalayn.asp.

[5] K. I. Nabeel, "Building Technology in the Holy Koran,” Building Sciences, 2012. [Online]. Available:

building-technology-in-the-holy-koran/.

[Accessed: 20-Feb-2005].

[6] M. Saifullah, "Were Burnt Bricks Used In Ancient Egypt In The Time of Moses?," Islamic Awareness, 2005. [Online]. Available: https:// www.islamic-awareness.org/quran/contrad/ external/burntbrick.

[7] A. Spencer, Brick Architecture In Ancient Egypt. UK: Aris \& Phillips Ltd., 1979.

[8] Y. Wazeri, "Roofs of silver, why silver?," E'ajaz journal, no. 5, pp. 7-11, 2018 .

[9] Q. Zhao, J. Yang, Z.-H. Wang, and E. A. Wentz, 
"Assessing the Cooling Benefits of Tree Shade by an Outdoor Urban Physical Scale Model at Tempe, AZ," Urban Science, vol. 2, no. 1, pp. 45, 2018.

[10] D. Pearson, The Natural House Book. London: Conran Octopus Limited, 1995.

[11] A. S. Barau, "Habitats of Ant, Bee and Spider in the Qur'an: Exploring Clues for Sustainable Urban Design," in SUSTAINABILITY THROUGH BIOMIMICRY Discovering a world of solutions inspired by nature Conference, 2012.

[12] Z. Mortice, "Nature Does It Better: Biomimicry in Architecture and Engineering," Architecture, 2016. [Online]. Available: https:// www.autodesk.com/redshift/biomimicry-inarchitecture/.

[13] J. Turner and R. Soar, "Beyond biomimicry: What termites can tell us about realizing the living building," in First International Conference on Industrialized, 2008 .

[14] L. Zyga, "Physicists Investigate Structural
Properties of Spider Webs," Phys Org, 2010. [Online]. Available: https://phys.org/news/2010 -02-physicists-properties-spider-webs.html.

[15] V. Gonzalez, Beauty and Islam. New York: I.B. Tauris \& Co Ltd, 2001.

[16] L. Chien-Yu, "Application of Low-cost Interactive Floors on Special Education and Assistive Technology," International Journal of Elementary Education, vol. 2, no. 1, pp. 1-7, 2013.

[17] L. Erlich, "The Swimming Pool Illusion," Twisted Sifter, 2012. [Online]. Available: https:// twistedsifter.com/2012/08/fake-swimmingpool-illusion-by-leandro-erlich.

[18] Y. Wazeri, "Exploring the Significance of Mecca Sacred Mosque Global Location," Journal of Islamic Architecture, vol. 4, no. 3, 2017.

[19] W. Tobler, "Qibla Maps," Qibla Maps, 2002. [Online]. Available: http:/l www.ncgia.ucsb.edu/projects/tobler/Qibla/ sldo01.htm 